\title{
Triosephosphate Isomerase Deficiency
}

National Cancer Institute

\section{Source}

National Cancer Institute. Triosephosphate Isomerase Deficiency. NCI Thesaurus. Code C131652.

A rare, autosomal recessive, inherited disorder caused by mutation of the TPI1 gene. It is characterized by hemolytic anemia and severe, progressive neuromuscular dysfunction beginning in early childhood. 